ORIGINAL ARTICLE

\title{
Synthesis of enriched biochar as a vehicle for phosphorus in tropical soils
}

\author{
Stella Cristiani Gonçalves MATOSO $1,2, * \mathbb{1}$, Paulo Guilherme Salvador WADT ${ }^{2,3}$, \\ Valdomiro Severino de SOUZA JÚNIOR ${ }^{4}$, Xosé Lois Otero PÉREZ 5 \\ Instituto de Educação, Ciência e Tecnologia de Rondônia, Campus Colorado do Oeste, BR 435, Km 63, Zona Rural, 76993-000 Colorado do Oeste, RO, Brasil \\ 2 Fundação Universidade Federal de Rondônia, Programa de Pós-Graduação em Biodiversidade e Biotecnologia, Rede Bionorte, BR 364, Km 9,5, 76801-059 Porto \\ Velho, RO, Brasil \\ Embrapa Rondônia, BR 364, Km 5,5, Zona Rural, 78900-970, Porto Velho, RO, Brasil \\ ${ }^{4}$ Universidade Federal Rural de Pernambuco, Departamento de Agronomia, Av. Dom Manoel de Medeiros, s/n, 52171-900 Recife, PE, Brasil \\ 5 Universidade de Santiago de Compostela, Departamento de Edafoloxía e Química Agrícola, Facultade de Bioloxía, Campus sur, 15782 Santiago de Compostela, Spain \\ * Corresponding author: stella.matoso@ifro.edu.br; (D) https://orcid.org/0000-0001-7851-5053
}

\section{ABSTRACT}

Phosphorus $(\mathrm{P})$ is one of the nutrients that most limits agricultural productivity, especially in tropical soils. Enriched biochar has been proposed to increase the bioavailability of $\mathrm{P}$ and other nutrients in the soil. Thus, the objective of this study was to evaluate the availability of $\mathrm{P}$ in phosphate biochar (composed of biomass and soil) as a function of the triple superphosphate mixture before and after the pyrolysis process. We produced eight types of enriched biochar via pyrolysis by combining sandy or clayey soil with rice or coffee husk, and by adding triple superphosphate before or after pyrolysis. The heating of the phosphate fertilizer during the pyrolysis process resulted in a higher crystallinity of the phosphates, lower content of labile fractions of $\mathrm{P}$ and lower content of available $\mathrm{P}$ in phosphate biochars than when the superphosphate was added after pyrolysis.

KEYWORDS: Amazonian soils; coffee husk; rice husk; pyrolysis; triple superphosphate; biochar quality

\section{Síntese de biocarvão enriquecido como veículo para fósforo em solos tropicais}

\section{RESUMO}

O fósforo $(\mathrm{P})$ é um dos nutrientes que mais limita a produtividade agrícola, principalmente em solos tropicais. Biocarvão enriquecido tem sido proposto com o intuito de incrementar a biodisponibilidade de $\mathrm{P}$ e de outros nutrientes no solo. Assim, objetivou-se avaliar a disponibilidade do fósforo em biocarvão fosfatado (composto de biomassa e solo) em função da mistura de superfosfato triplo antes e após o processo de pirólise. Produzimos oito tipos de biocarvão enriquecido via pirólise, combinando solo arenoso ou argiloso com casca de arroz ou de café, e adicionando superfosfato triplo antes ou depois da pirólise. O aquecimento do fertilizante fosfatado durante o processo de pirólise resultou em maior cristalinidade dos fosfatos, menor teor de fraçóes lábeis de P e menor teor de P disponível nos biocarvóes fosfatados do que quando o superfosfato foi adicionado após a pirólise.

PALAVRAS-CHAVE: solos amazônicos; casca de café; casca de arroz; pirólise; superfosfato triplo; qualidade do biocarvão

\section{INTRODUCTION}

Phosphorus $(\mathrm{P})$ is a primary macronutrient, required in large quantities in fertilization of crops, specially in tropical soils. It has been estimated that up to $90 \%$ of the soluble $\mathrm{P}$ applied in these soils rapidly assumes insoluble forms due to the fixation reactions of phosphate (Broggi et al. 2010; Behera et al. 2014). Therefore, the increase in agricultural production has resulted in high demand for phosphate fertilizers. In Brazil alone, 5 x $10^{-6} \mathrm{Mg}$ of $\mathrm{P}_{2} \mathrm{O}_{5}$ were consumed in 2017 , a $25 \%$ increase when compared to 2007 , and a $241 \%$ increase when compared to 1995 (IPNI 2018).
In this context, Amazonian Dark Earth (ADE) soils are an exception. These are soils, usually with a high degree of weathering, distinguished from other soils by their high level of fertility associated with the higher content of organic pyrogenic carbon (C) (Cunha et al. 2009; Macedo et al. 2017). The levels of available $P$ in these soils are considered very high and can reach 4,500 $\mathrm{mg} \mathrm{kg}^{-1}$ (Lima et al. 2002; Macedo et al. 2017). ADE pedogenesis has been attributed to a melanization process associated with homogenization of the soil through biological and human action (Macedo et al. 2017). 
Based on this knowledge, several experiments have been carried out to reproduce ADE (Novotny et al. 2015). In this sense, the biochar (C-rich solid material obtained by biomass pyrolysis) is intentionally produced and used as soil amendment to increase fertility or sequester atmospheric $\mathrm{CO}_{2}$ (Mukherjee et al. 2011). Biochar production in the presence of mineral additives has been proposed to obtain a new product (enriched biochar) to improve the bioavailability of inorganic nutrients to crop soils (Chia et al. 2012; 2014; Lin et al. 2013; Blackwell et al. 2015).

Enriched biochar is usually obtained by the pyrolysis of biomass at 350 to $600{ }^{\circ} \mathrm{C}$, followed by doping with clay minerals and diverse sources of nutrients, such as calcium carbonate, rock phosphate, poultry litter and liquid fertilizer, and subsequent drying $\left(105^{\circ} \mathrm{C}\right.$ ) or torrefaction (180 to 220 ${ }^{\circ} \mathrm{C}$ ) of the mixture (Lin et al. 2013; Chia et al. 2014; Kim et al. 2014; Blackwell et al. 2015). These products have high available P content, attributed to the strong interactions between clay mineral phases and organic acids during torrefaction, which blocks phosphate adsorption sites and increases the solubility of P (Lin et al. 2013; Chia et al. 2014).

The synthesis of ernriched biochars, though promising, increases operational and energy costs when compared to the traditional way of producing biochar, since it requires more stages of drying and torrefaction of the product (Lin $e t$ al. 2013; Chia et al. 2014; Kim et al. 2014; Blackwell et al. 2015). Therefore, it is important to test new methods and organomineral combinations to obtain enriched biochar. In the present study, we propose an alternative method to obtain enriched biochar (denominated phosphate biochar) through the pyrolysis of biomass mixed with mineral materials, thus rendering the doping process and subsequent drying and/or torrefaction unnecessary.

The biomasses (rice and coffee husks) were selected due to their high availability and worldwide distribution (Abbasi and Abbasi 2010). Mineral sources were chosen due to their location and availability. We used Amazonian soils to enrich biochar from areas near ADE sites, and the triple superphosphate is a typical phosphate fertilizer used as a source of $P$ in agriculture (Reetz Jr. 2016). Thus, the objective of this study was to evaluate the availability of $\mathrm{P}$ in enriched biochar (composed of biomass and soil) as a function of the triple superphosphate mixture before and after the pyrolysis process.

\section{MATERIAL AND METHODS}

Eight phosphate biochars consisting of organomineral mixtures were produced. Four biochars were obtained by the pyrolysis of biomass (rice or coffee husks) mixed with soil samples of sandy or clayey texture and phosphate fertilizer (triple superphosphate). Four other biochars were produced by the pyrolysis of the same combinations of biomass and soil samples but adding triple superphosphate after the pyrolysis process.
Rice and coffee husks were obtained from a grain processing company, dried in a forced ventilation oven at 105 ${ }^{\circ} \mathrm{C}$ for $48 \mathrm{~h}$ and milled in a Wiley knife mill (TE-340/Tecnal, Brazil) equipped with a $0.7 \mathrm{~mm}$ sieve. The soil samples were obtained in two areas of cultivated pasture (Brachiaria sp.), in the municipality of Cabixi, Rondônia state, Brazil, both adjacent to ADE sites. A soil profile was opened and classified in each area, and a single sample (approximately $30 \mathrm{~kg}$ ) was collected at the depth of 10-20 cm from each profile.

Soil and biochar analyses were carried out at the Soil Mineralogy Laboratory of Universidade Federal Rural de Pernambuco (Brazil) and the Edaphology and Agricultural Chemistry Laboratory at Universidad de Santiago de Compostela (Spain). The soil samples belonged to the order of Oxisols (Soil Survey Staff 2014), with a similar mineralogical composition characterized by the presence of kaolinite, goethite, hematite and gibbsite (Table 1). The soil analysis was performed in duplicate. The soil $\mathrm{pH}$ was measured in water $(1: 2.5)$ using a glass electrode. The total $\mathrm{C}$ and nitrogen $(\mathrm{N})$ were determined using an elemental analyzer (LECO model TruSpec CHNO, USA). The exchangeable cations, $\mathrm{Ca}^{2+}, \mathrm{Mg}^{2+}$ and $\mathrm{Al}^{3+}$, were extracted using $1.0 \mathrm{M}$ of $\mathrm{KCl}$ and measured with atomic absorption spectroscopy (Perkin Elmer 1100B, Germany). $\mathrm{H}^{+}$and $\mathrm{Al}^{3+}$ were extracted with calcium acetate $(0.5 \mathrm{M})$ at $\mathrm{pH} 7.0$ and determined by titration $(\mathrm{NaOH}$ at

Table 1. Chemical, granulometric and mineralogical properties of sandy and clayey Oxisol soil samples from Rondônia state (northern Brazil) used in the experimental composition of phosphate biochar.

\begin{tabular}{|c|c|c|}
\hline Property & Sandy & Clayey \\
\hline $\mathrm{pH}$ & 4.2 & 4.5 \\
\hline Total C (\%) & 0.47 & 1.32 \\
\hline Total N (\%) & 0.10 & 0.26 \\
\hline Available $\mathrm{P}\left(\mathrm{mg} \mathrm{kg}^{-1}\right)$ & 1.00 & 1.00 \\
\hline Available K $\left(\mathrm{mg} \mathrm{kg}^{-1}\right)$ & 0.05 & 0.05 \\
\hline Exchangeable $\mathrm{Ca}\left(\mathrm{cmol}_{\mathrm{c}} \mathrm{kg}^{-1}\right)$ & 0.15 & 0.48 \\
\hline Exchangeable $\mathrm{Mg}\left(\mathrm{cmol}_{\mathrm{c}} \mathrm{kg}^{-1}\right)$ & 0.08 & 0.15 \\
\hline Exchangeable $\mathrm{H}\left(\mathrm{cmol}_{\mathrm{c}} \mathrm{kg}^{-1}\right)$ & 1.70 & 4.90 \\
\hline Exchangeable Al $\left(\mathrm{cmol}_{\mathrm{c}} \mathrm{kg}^{-1}\right)$ & 1.00 & 0.60 \\
\hline Total Al $\left(\mathrm{g} \mathrm{kg}^{-1}\right)$ & 41.81 & 149.25 \\
\hline Al-ox $\left(\mathrm{g} \mathrm{kg}^{-1}\right)$ & 0.50 & 2.32 \\
\hline Total Fe $\left(\mathrm{g} \mathrm{kg}^{-1}\right)$ & 13.99 & 10.71 \\
\hline Fe-ox $\left(\mathrm{g} \mathrm{kg}^{-1}\right)$ & 0.14 & 1.54 \\
\hline Sand $\left(\mathrm{g} \mathrm{kg}^{-1}\right)$ & 784 & 292 \\
\hline Silt $\left(\mathrm{g} \mathrm{kg}^{-1}\right)$ & 95 & 104 \\
\hline Clay $\left(\mathrm{g} \mathrm{kg}^{-1}\right)$ & 121 & 604 \\
\hline Mineralogy & $\begin{array}{l}\text { Kaolinite, goethite, } \\
\text { gibbsite }\end{array}$ & $\begin{array}{l}\text { Kaolinite, goethite, } \\
\text { hematite, gibbsite }\end{array}$ \\
\hline
\end{tabular}

Al-ox: oxalate extractable Al; Fe-ox: oxalate extractable. 
$0.025 \mathrm{M})$. Available potassium $(\mathrm{K})$ and $\mathrm{P}$ were extracted with a Mehlich ${ }^{-1}$ solution. K was determined by flame photometry (Perkin Elmer 1100B, Germany), and P was measured using colorimetry (JASCO V630, Japan) (Sparks et al. 1996).

The total iron $(\mathrm{Fe})$ and aluminum $(\mathrm{Al})$ content were determined by acid digestion using nitric acid, hydrogen peroxide and hydrochloric acid (5:3:5) and measured by atomic absorption spectroscopy (Perkin Elmer 1100B, Germany) (Kimbrough and Wakakuwa 1989). The amorphous Fe and Al oxyhydroxides ( $\mathrm{Fe}$-ox and $\mathrm{Al}$-ox) were obtained by extraction with ammonium oxalate $(\mathrm{pH}$ 3.0) in a dark environment, and the quantification of $\mathrm{Fe}$ and $\mathrm{Al}$ was performed by atomic absorption spectroscopy (Perkin Elmer 1100B, Germany) (Sparks et al. 1996). The mineralogy was determined from samples in the form of non-oriented powder. X-ray diffraction (XRD) analysis was performed using a XRD diffractometer with $\mathrm{Cu} \mathrm{K \alpha}$ radiation (Shimadzu 6000-XRD, Japan). The X-ray source was operated at $40 \mathrm{kV}$ and $30 \mathrm{~mA}$. The instrument was equipped with a graphite monochromator. The scan rate was $1^{\circ} 2 \theta$ min- 1 from 3 to $70^{\circ}(2 \theta)$.

According to their granulometric composition, the soil samples were designated as sandy ( sand $=784 \mathrm{~g} \mathrm{~kg}^{-1}$ ) or clayey $\left(\right.$ clay $\left.=604 \mathrm{~g} \mathrm{~kg}^{-1}\right)$. The sandy sample was characterized by a very acidic reaction $(\mathrm{pH}=5.2)$, low content of total $\mathrm{C}$ and $\mathrm{N}$, low cation exchange capacity (CEC) and was dominated by exchangeable $\mathrm{Al}$ and $\mathrm{H}$. The clayey sample had similar characteristics, but the contents of amorphous $\mathrm{Fe}$ and $\mathrm{Al}$ oxyhydroxides ( $\mathrm{FeOx}$ and $\mathrm{AlOx}$ ) were 3 to 10 times greater, respectively, than those in the sandy sample.

Part of the soil samples were dried in an oven $\left(105^{\circ} \mathrm{C}\right.$ for $48 \mathrm{~h}$ ) and sieved with a $2-\mathrm{mm}$ mesh, then mixed with the organic material (either rice or coffee husk) in the proportion of 1.5:1.0 (biomass:soil). The solid mixture was placed in closed aluminum containers, and pyrolysis proceeded in a muffle at $350{ }^{\circ} \mathrm{C}$ for $2 \mathrm{~h}$, discounting the equipment heating time and material cooling time to room temperature (Cao and Harris 2010; García-Jaramillo et al. 2015; Tian et al. 2017). The four biochars obtained were mixed after pyrolysis with triple superphosphate (macerated) at a ratio of 0.65:0.35 (biochar:fertilizer). This ratio was chosen to maintain a proportion similar to that of other studies on biochars enriched with minerals (Lin et al. 2013; Chia et al. 2014). The mixture was homogenized in an agate mortar, sieved with a $0.177-\mathrm{mm}$ mesh and stored in polyethylene containers at room temperature. These phosphate biochars were designated as:

RiS+P: biochar derived from rice husk + sandy soil + triple superphosphate added after pyrolysis;

$\mathrm{RiC}+\mathrm{P}$ : biochar derived from rice husk + clayey soil + triple superphosphate added after pyrolysis;
CfS+P: biochar derived from coffee husk + sandy soil + triple superphosphate added after pyrolysis;

CfC+P: biochar derived from coffee husk + clayey soil + triple superphosphate added after pyrolysis.

The other part of the soil was dried and seived in the same way, then mixed with the organic material (either rice or coffee husk) and triple superphosfate in the proportion of 1.5:1.0:1.0 (biomass:soil:triple superphosphate). These proportions were adopted according to the mass loss control of the mixtures and the raw materials isolated during the pyrolysis by mass calibration before and after the heat treatment. A final composition of approximately 0.27:0.38:0.35 (biochar:soil:triple superphosphate) was obtained. The resulting four phosphate biochars were defined as:

P-RiS: biochar derived from rice husk + sandy soil + triple superphosphate added before pyrolysis;

P-RiC: biochar derived from rice husk + clayey soil + triple superphosphate added before pyrolysis;

P-CfS: biochar derived from coffee husk + sandy soil + triple superphosphate added before pyrolysis;

P-CfC: biochar derived from coffee husk + clayey soil + triple superphosphate added before pyrolysis.

The crystallographic structure of the biochar samples was qualitatively analyzed in the same form as described above for the soil samples. The quantitative physicochemical parameters were determined in duplicate for all biochars according to Klmbrough and Wakakuwa (1989) and Gaskin et al. (2008). $\mathrm{pH}$ was measured using a digital $\mathrm{pH}$ meter, with a biochar to deionized water ratio of 1:5, after stirring for $5 \mathrm{~min}$ and $1 \mathrm{~h}$ equilibration. Elemental $\mathrm{C}$ analysis was conducted using an elemental analyzer (LECO model TruSpec CHNO, USA).

The total content of potassium $(\mathrm{K})$, calcium $(\mathrm{Ca})$, magnesium $(\mathrm{Mg})$, iron $(\mathrm{Fe})$, aluminum $(\mathrm{Al})$, manganese $(\mathrm{Mn})$ and phosphorus $(\mathrm{P})$ was determined in samples macerated and sieved with a $0.074-\mathrm{mm}$ mesh. $\mathrm{K}, \mathrm{Ca}, \mathrm{Mg}, \mathrm{Fe}$ and $\mathrm{Al}$ were analyzed by X-ray fluorescence using a Rigaku ZSX Primus II X-ray fluorescence spectrometer (Japan), equipped with a Rh tube and seven-crystal analyzer, after six previous calibrations with different certified reference materials (for sediments and soils) from NIST (SRM 1333, SRM 1646, SRM 2710, SRM 2711), Canadian Certified Reference Material Project (LKSD1, LKSD2, LKSD3, LKSD4) and USGS (MAG1, G2). Total Mn and P were extracted with acidic digestion at $90{ }^{\circ} \mathrm{C}$ using nitric acid, hydrogen peroxide and hydrochloric acid (5:3:5). Mn was measured with atomic absorption spectroscopy (Perkin Elmer 1100B, Germany), while the $\mathrm{P}$ content was determined by the colorimetric method with absorbance measured at $880 \mathrm{~nm}$ using a JASCO spectrophotometer model V630 (Japan). 
The available $\mathrm{P}$ content was extracted with neutral ammonium citrate + water (NAC + water) and determined by the colorimetric method with absorbance measured at 420 $\mathrm{nm}$ (Wang et al. 2012). Sequential fractionation of $\mathrm{P}$ was performed by adapting the method described by Ruttenberg (1992). The samples of biochar $(0.5 \mathrm{~g})$ were extracted stepwise using [1] $\mathrm{MgCl}_{2}(1 \mathrm{M})$, [2] $\mathrm{NaHCO}_{3}(0.11 \mathrm{M})+$ $\mathrm{Na}_{2} \mathrm{~S}_{2} \mathrm{O}_{4}(0.11 \mathrm{M})$, [3] $\mathrm{NaOH}(0.1 \mathrm{M})$, and [4] $\mathrm{HCl}(0.5$ $\mathrm{M})$. The $\mathrm{P}$ content in the extracts was then determined by the colorimetric method measured by spectrophotometry at 880 $\mathrm{nm}$, and corresponds to [1] P poorly adsorbed and soluble (labile P), [2] P associated with Fe oxyhydroxides (Fe-P), [3] $\mathrm{P}$ bonded to clay minerals and hydroxides of $\mathrm{Al}$ (Al-P), and [4] P associated with calcium (Ca-P).

The extracts from step [3] were acidified with $\mathrm{H}_{2} \mathrm{SO}_{4}$ (1:5) to $\mathrm{pH} \approx 1$, and, after $16 \mathrm{~h}$, they were filtered. The filters were dried $\left(40{ }^{\circ} \mathrm{C}\right.$ for $\left.12 \mathrm{~h}\right)$, calcinated $\left(520^{\circ} \mathrm{C}\right.$ for $\left.2 \mathrm{~h}\right)$ and digested in $\mathrm{HCl}(1 \mathrm{M})$ for the determination of $\mathrm{P}$ associated with humic substances (HS-P). The black-carbon P (BC-P) was obtained by calcination $\left(520^{\circ} \mathrm{C}\right.$ for $\left.2 \mathrm{~h}\right)$ and digestion $(1$ $\mathrm{M} \mathrm{HCl})$ of the biochar samples after extraction. The difference between total $\mathrm{P}$ content and the sum of all the determined fractions was considered a form of occluded P.

The ability of the biochars to adsorb phosphate was determined in samples of biochars derived from mixtures of biomass and soil without the addition of triple superphosphate, designated as RiS (rice husk + sandy soil), RiC (rice husk + clayey soil), CfS (coffee husk + sandy soil) and CfC (rice husk + clayey soil). Two grams of each material (in duplicate) were conditioned in 50-ml centrifuge tubes, adding $20 \mathrm{ml}$ of 0.01 $\mathrm{M} \mathrm{KCl}$ solution containing $0,15,30,60,120$, and $240 \mathrm{mg} \mathrm{L}^{-1}$ of $\mathrm{P}$ in the form of monopotassium phosphate $\left(\mathrm{KH}_{2} \mathrm{PO}_{4}\right)$. The samples were shaken for $24 \mathrm{~h}$ at room temperature, centrifuged at $3,200 \mathrm{~g}$ for $10 \mathrm{~min}$ and filtered. Tubes filled with P solutions but without biochar were analyzed to determine $\mathrm{P}$ sorption on the surfaces of the tubes and filters. The remaining $P$ content in the extracts was determined by the colorimetric method measured by spectrophotometry at $880 \mathrm{~nm}$ (JASCO V630, Japan) (Graetz and Nair 2000).

The adsorbed $\mathrm{P}$ content was determined by the difference between the initial $\mathrm{P}$ concentration in the solution and the remaining $\mathrm{P}$ concentration in the equilibrium solution. For the samples in which $\mathrm{P}$ retention was found, the content of adsorbed $\mathrm{P}$ at each dose was adjusted by the Langmuir equation:

$$
\mathrm{Q}=\left(\mathrm{K}_{\mathrm{L}} \times \mathrm{Qmax} \times \mathrm{Ceq}\right) /\left[1+\left(\mathrm{K}_{\mathrm{L}} \times \mathrm{Ceq}\right)\right]
$$

where $\mathrm{Q}$ is the total amount of adsorbed $\mathrm{P}\left(\mathrm{mg} \mathrm{kg}^{-1}\right)$; $\mathrm{K}_{\mathrm{L}}$ is a constant related to the binding strength; $\mathrm{Qmax}$ is the sorption maximum $\left(\mathrm{mg} \mathrm{kg}^{-1}\right)$; and Ceq is the concentration of $\mathrm{P}$ remaining in the solution after the $24 \mathrm{~h}$ equilibrium $\left(\mathrm{mg} \mathrm{L}^{-1}\right)$.
Principal component analysis (PCA) was performed to evaluate the relative importance of biochar physicochemical components and phosphorus availability. Statistical analysis was performed in the Xlstat software (Addinsoft 2016).

\section{RESULTS}

Although the mineralogy of the two soil samples was similar (Table 1), the clayey sample still contained hematite (Figure 1a). The biochars preserved the soil minerals, except for gibbsite (Figures 1a, b), which collapsed due to the temperature reached during pyrolysis (Cornell and Schwertmann 2003; Löhr et al. 2017).

The biochars that were amended with triple superphosphate before pyrolysis (P-RiS, P-RiC, P-CfS and P-CfC) presented $\mathrm{XRD}$ peaks related to the presence of phosphates, characterized as leucophosphite (potassium and iron phosphate), fluorapatite (calcium halophosphate) and hydroxyapatite (calcium phosphate) (Figures 1c, d). These minerals were also observed in the original composition of the triple superphosphate and persisted in the fertilizer after heating at $350^{\circ} \mathrm{C}$ for $2 \mathrm{~h}$ (Figure 1b). However, the heat treatment of the phosphate fertilizer resulted in a higher degree of crystallinity of the phosphates, identified by a higher peak intensity (Figure 1b).

Phosphate neoformation in the biochars and in the superheated triple superphosphate alone was not observed (Figures 1b, c, d). Peaks corresponding to bassanite $\left(\beta-\mathrm{CaSO}_{4} \cdot 1 / 2 \mathrm{H}_{2} \mathrm{O}\right)$ and anhydrite $\left(\mathrm{CaSO}_{4}\right)$ were also identified in triple superphosphate (in natura), but only the bassanite persisted after the heat treatment (Figure 1b). This pattern was repeated in P-RiS, P-RiC, P-CfS and P-CfC (Figures 1c, d).

The $\mathrm{pH}$ of our phosphate biochars was characterized by a very acidic reaction, varying from 3.0 to 4.1 (Table 2), due to the low $\mathrm{pH}$ of the triple superphosphate (2.8). The coffee husk (CfS+P, CfC+P, P-CfS and P-CfC) provided higher $\mathrm{pH}$ in relation to the rice husk ( $\mathrm{RiS}+\mathrm{P}, \mathrm{RiC}+\mathrm{P}, \mathrm{P}-\mathrm{RiS}$ and $\mathrm{P}-\mathrm{RiC})$.

The raw material and the triple superphosphate addition method influenced the elemental composition of the phosphate biochars. Biochars derived from clayey soil had lower total Ca content (up to 26\%) and higher amounts of $\mathrm{Al}$ and $\mathrm{Fe}$ (up to $356 \%$ and $423 \%$, respectively) in relation to biochars from sandy soil (Table 2). Mn content was higher (up to $76 \%$ ) and $\mathrm{K}$ content was lower (by $78 \%$ ) in rice-husk than in coffee-husk biochars (Table 2). Biochars phosphated prior to pyrolysis had higher $\mathrm{C}$ content (up to $47 \%$ ) than those phosphated after pyrolysis. Total $\mathrm{P}$ content of the phosphate biochars ranged from 70.1 to $82.3 \mathrm{~g} \mathrm{~kg}^{-1}$ (Table 2).

The heat treatment of the triple superphosphate affected the available $P$ content and the distribution of the different forms of $\mathrm{P}$ in the samples (Table 3). Biochars phosphated prior to pyrolisis had lower available $\mathrm{P}$ content (up to $43 \%$ ), lower content of the labile P fraction and higher Fe-P, Ca-P, BC-P and occluded P when compared to biochars phosphated after pyrolysis. 
A

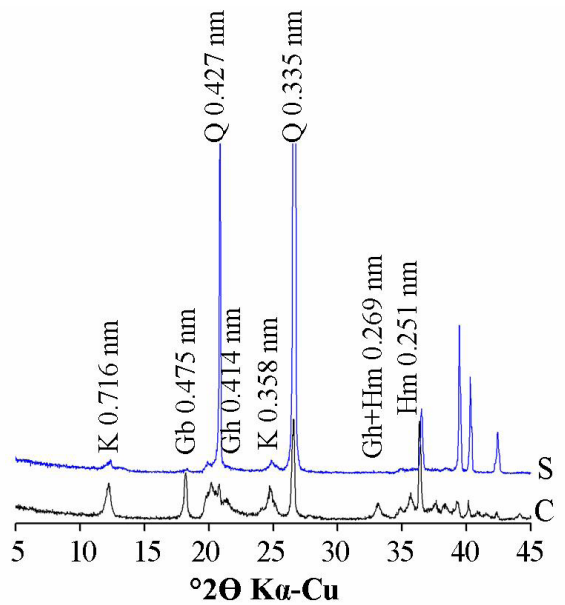

$\mathrm{C}$

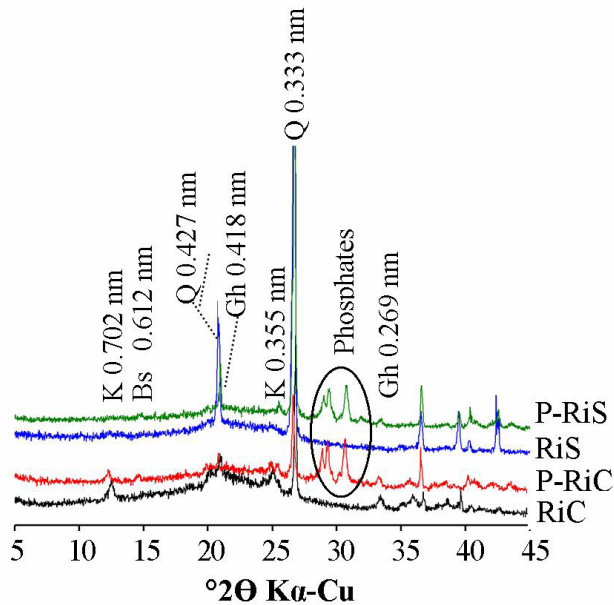

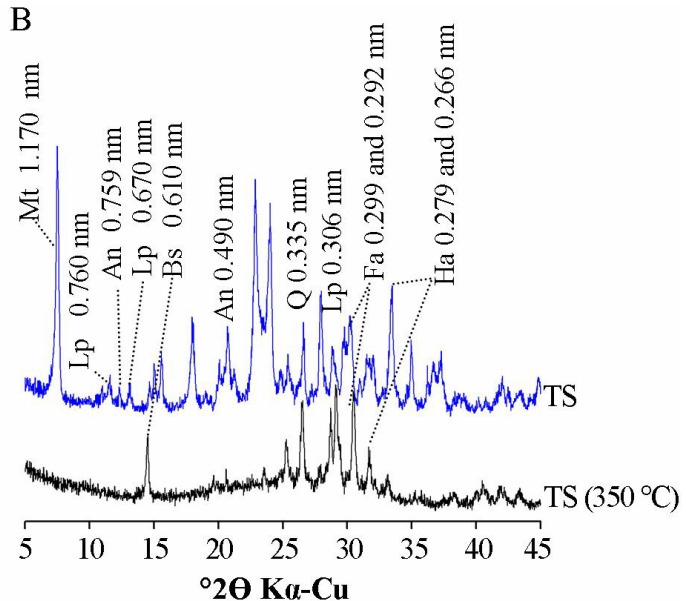

$\mathrm{D}$

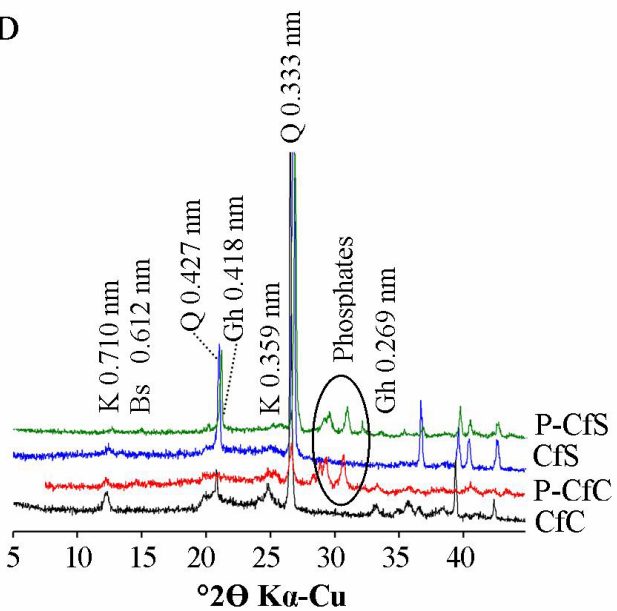

Figure 1. XRD patterns of mineral feedstock and phosphate biochars derived from rice and coffee husk mixed with sandy and clayey Oxisol soil samples from Rondônia state (northern Brazil). A: sandy (S) and clayey (C) Oxisol; B: triple superphosphate in natura (TS) and heated triple superphosphate - TS ( $\left.350^{\circ} \mathrm{C}\right)$; C: biochar derived from rice husk + sandy soil (RiS), biochar derived from rice husk + clayey soil (RiC), biochar derived from rice husk + sandy soil + triple superphosphate added before pyrolysis (P-RiS) and biochar derived from rice husk + clayey soil + triple superphosphate added before pyrolysis (P-RiC); D: biochar derived from coffee husk + sandy soil (CfS), biochar derived from coffee husk + clayey soil (CfC), biochar derived from coffee husk + sandy soil + triple superphosphate added before pyrolysis (P-CFS) and biochar derived from coffee husk + clayey soil + triple superphosphate added before pyrolysis (P-CfC). K: kaolinite; Q: quartz; Gb: gibbsite; Gh: goethite; Hm: hematite; Mt: matiolite; Lp: leucophosphite; An: anhydrite; Bs: bassanite; Fa: fluorapatite; Ha: hydroxyapatite. This figure is in color in the electronic version.

Table 2. $\mathrm{pH}\left(\mathrm{H}_{2} \mathrm{O}\right)$ and elemental composition $\left(\mathrm{g} \mathrm{kg}^{-1}\right)$ of eight experimental phosphate biochars derived from rice and coffee husk mixed with sandy and clayey Oxisol soil samples from Rondônia state, northern Brazil.

\begin{tabular}{lccccccccc}
\hline Biochars & $\mathrm{pH}$ & $\mathrm{C}$ & $\mathrm{P}$ & $\mathrm{Ca}$ & $\mathrm{Mg}$ & $\mathrm{K}$ & $\mathrm{Al}$ & $\mathrm{Fe}$ & $\mathrm{Mn}$ \\
\hline RiS+P & 3.5 & 130.80 & 74.38 & 90.77 & 2.41 & 6.64 & 11.11 & 8.55 & 0.29 \\
RiC+P & 3.8 & 158.40 & 74.79 & 71.47 & 1.81 & 4.98 & 41.28 & 43.48 & 0.30 \\
CfS+P & 4.1 & 158.00 & 72.57 & 103.63 & 3.02 & 29.89 & 11.64 & 9.27 & 0.16 \\
CfC+P & 4.1 & 184.90 & 70.08 & 77.19 & 2.41 & 27.40 & 46.05 & 48.47 & 0.17 \\
P-RiS & 3.0 & 192.50 & 75.51 & 88.62 & 2.41 & 6.64 & 8.47 & 8.55 & 0.31 \\
P-RiC & 3.1 & 173.50 & 73.17 & 72.19 & 1.81 & 4.98 & 38.64 & 46.33 & 0.30 \\
P-CfS & 3.8 & 176.20 & 82.30 & 92.91 & 2.41 & 29.89 & 10.06 & 9.27 & 0.17 \\
P-CfC & 4.0 & 198.30 & 72.79 & 81.48 & 2.41 & 26.57 & 39.69 & 47.05 & 0.17
\end{tabular}

RiS: biochar derived from rice husk + sandy soil; RiC: biochar derived from rice husk + clayey soil; CfS: biochar derived from coffee husk + sandy soil; CfC: biochar derived from coffee husk + clayey soil; +P: triple superphosphate added after pyrolysis; P-: triple superphosphate added prior to pyrolysis.
Table 3. Available $P\left(\mathrm{~g} \mathrm{~kg}^{-1}\right)$ and $P$ fractions $\left(\mathrm{g} \mathrm{kg}^{-1}\right)$ of eight experimental phosphate biochars derived from rice and coffee husk mixed with sandy and clayey soils Oxisol soil samples from Rondônia state, northern Brazil.

\begin{tabular}{lcccccccc}
\hline \multirow{2}{*}{ Biochars } & Available & \multicolumn{8}{c}{ P fractions } \\
\cline { 2 - 9 } & Labile P & Fe-P & Al-P & HS-P & Ca-P & BC-P & Occluded P \\
\hline RiS+P & 60.31 & 58.33 & 1.58 & 5.98 & 0.32 & 5.50 & 0.07 & 2.59 \\
RiC+P & 70.22 & 60.24 & 2.66 & 11.91 & 0.67 & 5.87 & 0.31 & -6.87 \\
CfS+P & 61.82 & 62.07 & 2.97 & 6.10 & 0.40 & 6.45 & 0.10 & -5.53 \\
CfC+P & 69.17 & 57.56 & 2.20 & 8.32 & 0.65 & 5.43 & 0.44 & -4.52 \\
P-RiS & 42.77 & 31.80 & 1.70 & 5.90 & 0.60 & 18.90 & 1.75 & 14.87 \\
P-RiC & 40.35 & 19.51 & 2.68 & 13.60 & 1.50 & 14.94 & 3.65 & 17.29 \\
P-CfS & 38.08 & 28.19 & 1.09 & 5.73 & 0.71 & 22.43 & 1.36 & 22.78 \\
P-CfC & 41.79 & 17.45 & 1.64 & 10.79 & 1.18 & 19.09 & 3.42 & 19.22 \\
\hline
\end{tabular}

RiS: biochar derived from rice husk + sandy soil; RiC: biochar derived from rice husk + clayey soil; CfS: biochar derived from coffee husk + sandy soil; CfC: biochar derived from coffee husk + clayey soil; $+\mathrm{P}$ : triple superphosphate added after pyrolysis; P-: triple superphosphate added prior pyrolysis. 
Biomass type did not change the availability of $\mathrm{P}$ in the phosphate biochars, with a variation of less than $8.5 \%$ in the available $\mathrm{P}$ content. Soil texture affected the distribution of $\mathrm{P}$ forms, as clayey-soil phosphated biochars had higher contents of Al-P, Fe-P and HS-P fractions (up to $131 \%, 68 \%$, and $151 \%$, respectively) than sandy-soil phosphate biochars (Table 3). Al-P content was higher than that of Fe-P in all phosphate biochars (Table 3).

The remaining $\mathrm{P}$ concentration determined in the equilibrium solution $(24 \mathrm{~h}$ ) was higher than the $\mathrm{P}$ added at all doses applied to the RiS, CfS and CfC biochars (Table 4). In $\mathrm{RiC}$, however, the remaining $\mathrm{P}$ content was lower than the added $\mathrm{P}$. The adjustment of the $\mathrm{P}$ content adsorbed by the Langmuir equation (Figure 2) resulted in $\mathrm{Qmax}$ of $\mathrm{P}=769.23$ $\mathrm{mg} \mathrm{kg}{ }^{-1}$, with $\mathrm{K}_{\mathrm{L}}=0.06$. However, no difference in available $\mathrm{P}$ content was observed in $\mathrm{RiC}+\mathrm{P}$ and $\mathrm{P}-\mathrm{RiC}$ (which were derived from $\mathrm{RiC}$ ) when compared to the other biochars (Table 3).

All variables determined for the eight phosphate biochars were used in the PCA, except total P content, due to the small correlation with the other variables and its high proximity to the centroid (data not shown). The F1 and F2 axes of the PCA accumulated $71 \%$ of the variance in the original data matrix (Figure 3). Biochars were grouped by phosphate-addition timing along the $\mathrm{F} 1$ axis ( $40.5 \%$ variance). Biochars phosphated after pyrolysis $(\mathrm{RiS}+\mathrm{P}, \mathrm{RiC}+\mathrm{P}, \mathrm{CfS}+\mathrm{P}$ and $\mathrm{CfS}+\mathrm{P})$ were defined mainly by the higher content of available $\mathrm{P}$ and labile $\mathrm{P}$, while biochars phosphated prior to pyrolysis (P-RiS, P-RiC, P-CfS and $\mathrm{P}-\mathrm{CfC}$ ) were characterized by the higher content of total C, BC-P, HS-P, Ca-P and occluded P. Along the F2 axis (30.5\%
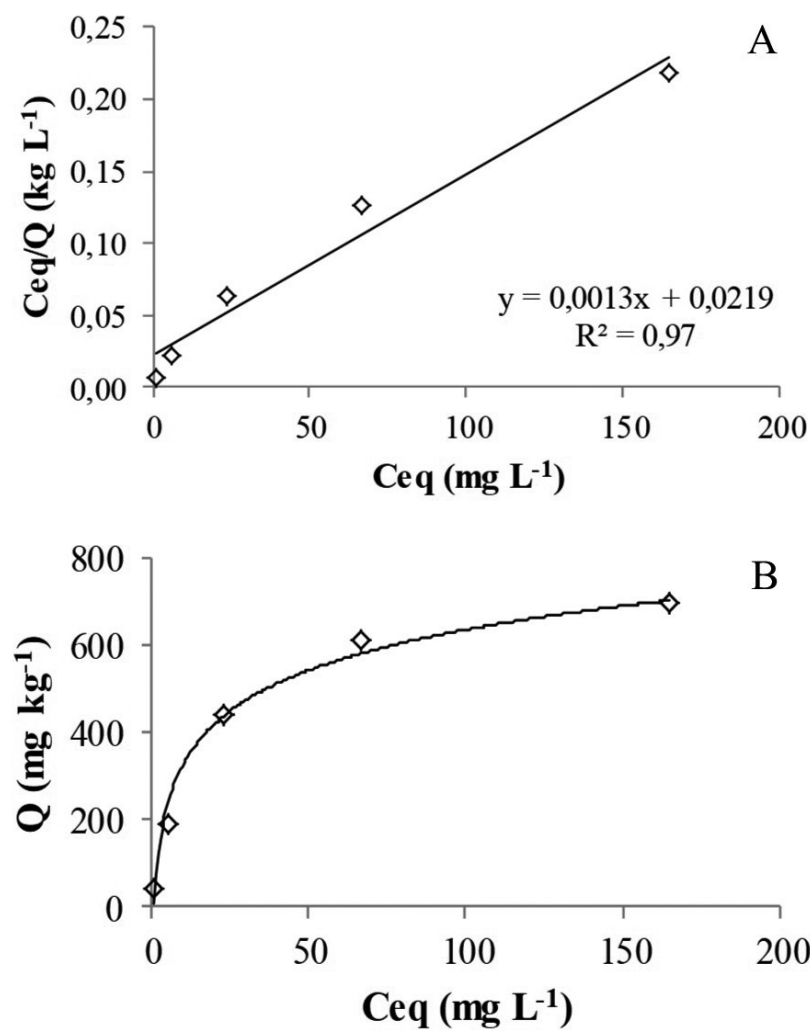

Figure 2. Phosphorus adsorption isotherms for biochar derived from rice husk mixed with clayey Oxisol soil samples from Rondônia state (northern Brazil). A: data linearization by Langmuir model; $B$ : Langmuir adsorption isotherms adjusted by linear regression. Q: total amount of adsorbed $\mathrm{P}\left(\mathrm{mg} \mathrm{kg}^{-1}\right)$; Ceq concentration of remaining $P$ in the solution after the 24 -h equilibrium $\left(\mathrm{mg} \mathrm{L}^{-1}\right)$.

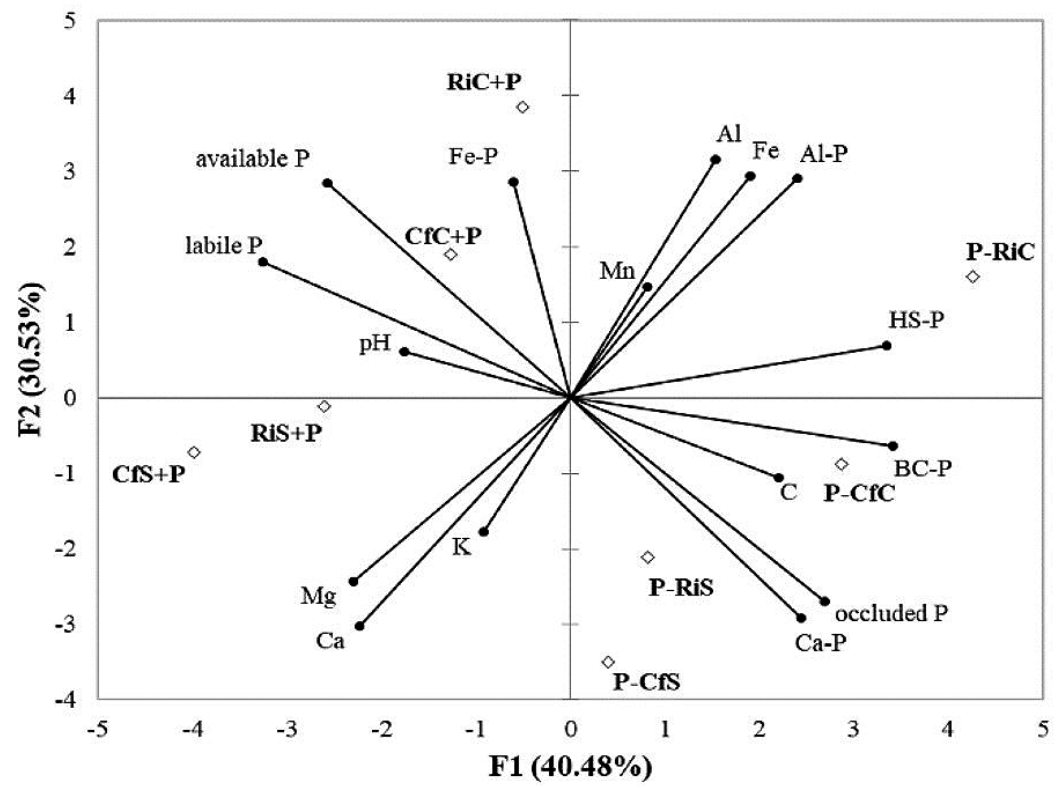

Figure 3. Ordering diagram derived from the principal component analysis of the physicochemical properties of eight experimental phosphate biochars derived from sandy and clayey Oxisol soil samples and rice and coffee husk. Percentage (\%) on axes F1 and F2 indicate cumulative percentage of the variance in the original data matrix. RiS: biochar derived from rice husk + sandy soil; RiC: biochar derived from rice husk + clayey soil; CfS: biochar derived from coffee husk + sandy soil; CfC: biochar derived from coffee husk + clayey soil; +P: triple superphosphate added after pyrolysis; P-: triple superphosphate added before pyrolysis. 
Table 4. Remaining $P$ in the equilibrium solution $\left(\mathrm{mg} \mathrm{L}^{-1}\right)$ of biochars derived from rice and coffee husk mixed with sandy and clayey Oxisol soil samples from Rondônia state (northern Brazil) when the samples were loaded with solutions containing different levels of $\mathrm{P}\left(\mathrm{mg} \mathrm{L}^{-1}\right)$.

\begin{tabular}{lcccc}
\hline \multirow{2}{*}{ Added P } & \multicolumn{4}{c}{ Remaining P } \\
\cline { 2 - 5 } & RiS & RiC & CfS & CfC \\
\hline 0 & 2.81 & 37.67 & 0.19 & 36.64 \\
15 & 18.79 & 52.02 & 0.93 & 46.08 \\
30 & 33.47 & 44.87 & 5.51 & 57.58 \\
60 & 61.69 & 94.21 & 23.18 & 78.79 \\
120 & 177.50 & 147.95 & 66.92 & 256.84 \\
240 & 532.18 & 291.42 & 164.67 & 527.69 \\
\hline
\end{tabular}

RiS: biochar derived from rice husk + sandy soil; RiC: biochar derived from rice husk + clayey soil; CfS: biochar derived from coffee husk + sandy soil; CfC: biochar derived from coffee husk + clayey soil.

variance) the biochars were grouped according to soil texture, influenced by total $\mathrm{Al}$, total $\mathrm{Fe}$ and $\mathrm{Al}-\mathrm{P}$, which had a negative correlation with $\mathrm{Ca}, \mathrm{Mg}$ and $\mathrm{K}$ levels. The type of biomass had no influence on the grouping of biochars along in the PCA axes, as $\mathrm{pH}, \mathrm{Mn}$ and $\mathrm{K}$ content did not correlate with the other variables that influenced the groupings.

\section{DISCUSSION}

Total P content was not affected in any of our biochars, because there are no $\mathrm{P}$ losses at low pyrolysis temperature $\left(350{ }^{\circ} \mathrm{C}\right)$, and temperatures of more than $760{ }^{\circ} \mathrm{C}$ are needed to vaporize P (Knicker 2007). On the other hand, the form of triple superphosphate incorporation was the determining factor of $\mathrm{P}$ availability in the biochars. Studies of sintering used to obtain ceramic and biomedical materials showed a significant positive correlation between temperature and the degree of crystallinity of phosphates (Denry and Holloway 2014; Ramirez-Gutierrez et al. 2017). Thus, lower available $\mathrm{P}$ and labile $\mathrm{P}$, and higher $\mathrm{Ca}-\mathrm{P}$ and occluded $\mathrm{P}$ in biochars phosphated prior to pyrolysis can be explained as a consequence of the increased degree of crystallinity of the phosphates. Similar results were found with the increase in the pyrolysis temperature of biomass (Cao and Harris 2010) and the heat treatment of organomineral mixtures containing biochar (Kim et al. 2014).

The increase of HS-P and BC-P fractions in the biochars phosphated prior to pyrolysis demonstrated that, although the product was formulated from a solid mixture, the organic molecules in the liquid and gas forms produced during thermal decomposition of the biomass reacted with the mineral fraction forming organomineral compounds. A similar reaction occurred in the clayey-soil biochars, which had a higher content of HS-P when compared to sandy-soil biochars. This premise is supported by other studies (Lin et al. 2013; Chia et al. 2014; Yao et al. 2014).

The presence of mineral elements during pyrolysis may have contributed to the greater conservation of $\mathrm{C}$ in the biochars. Meszaros et al. (2007) evaluated the thermal degradation of different biochars and found that materials with higher mineral content, such as $\mathrm{K}, \mathrm{P}, \mathrm{Mg}$ and $\mathrm{Na}$, emit less $\mathrm{CO}_{2}$ during decomposition. Corroborating this premise, pyrolysis in conjunction with triple superphosphate increased the total $\mathrm{C}$ content of the our biochars.

Our data indicate that, in order to use enriched biochar as a vehicle for phosphorus in tropical soils, it is more appropriate to mix triple superphosphate after pyrolysis, as in this way the highest available P content and lower content of the most recalcitrant fractions of $\mathrm{P}$ were obtained. The addition of the superphosphate prior to pyrolysis can be better studied in soils that occur losses of P by leaching.

The groups formed along the F2 axis of the PCA can be explained by the texture classes of the soils used and the result of the heating of these soils. Higher clay content provided more available sites for bonding with P. Thus, the Al-P fraction, which represents the $\mathrm{P}$ associated with the clay minerals and hydroxides of Al (Ruttenberg 1992), was higher in the biochars composed with clayey soil. This was due to the higher Al-ox content in comparison to Fe-ox (Table 1), as low-crystallinity $\mathrm{Al}$ compounds have a high affinity for $\mathrm{P}$ (Cui and Weng 2013; Eriksson et al. 2015).

The soil mineralogy influenced the Al-P fraction. Kaolinite and goethite observed in the soil samples were maintained in the biochars. The presence of goethite in biochars was not expected, but this mineral was identified by the peaks at 0.418 and $0.269 \mathrm{~nm}$ (XRD) in the biochars produced with clayey soil. The goethite likely underwent partial substitution (up to one third) of $\mathrm{Fe}^{3+}$ by $\mathrm{Al}^{3+}$, leading to a higher thermal resistance (up to $400^{\circ} \mathrm{C}$ ) (Cornell and Schwertmann 2003). In addition, the gibbsite was dehydroxylated during heat treatment (Löhr et al. 2017), therefore the reactivity of this mineral was increased (Kitamura et al. 2001), contributing to the higher Al-P content in the biochars composed with clayey soil.

The reaction of the $\mathrm{Fe}$ oxides during the pyrolysis process cannot be clarified by the analytical techniques used. Neoformation of magnetic Fe oxide could have occurred during pyrolysis $\left(350{ }^{\circ} \mathrm{C}\right)$ of biomass (Cornell and Schwertmann 2003), but the magnetite and/or maghemite peaks ( 0.253 and $0.297 \mathrm{~nm}$ ) (Schaetzl and Anderson 2005) were not observed in the biochars, nor was a hematite peak $(0.251 \mathrm{~nm})$. A possible explanation for these results is that part of the hematite was reduced to magnetite, but in an insufficient quantity to be detected by XRD. Also, the increase of noise in the XRD patterns of the C-rich material made it difficult to identify the Fe oxide peaks (Cornell and Schwertmann 2003).

A comparison of the groups formed along the PCA F2 axis with the results of the adsorption of $\mathrm{P}$ and the fractionation of $\mathrm{P}$ indicated that the higher content of Al-P, Fe and $\mathrm{Al}$, associated with the lower labile P fraction in the clayey-soil biochars, did not affect the available $P$ content of these biochars. Adsorption 
rate of $\mathrm{P}$ is mainly controlled by specific surface area, total pore volume, and average pore diameter of the biochar (Jiang et al. 2018). As these properties of biochars have an inverse relationship with the pyrolysis temperature (Brewer et al. 2014), the biochars produced at $350^{\circ} \mathrm{C}$ did not have the ability to adsorb P. Furthermore, the fractionation of $\mathrm{P}$ is carried out sequentially with extractors of lower and higher reactivity to the different $\mathrm{P}$ phases, thus allowing the separation of labile, moderately labile and non-labile forms of $\mathrm{P}$ (Ruttenberg 1992). Therefore, part of the Al-P and Fe-P fractions is still bioavailable and can be extracted with NAC + water, specially when formed by monodentate bonds (Tan 1998).

Larger differences in the total $\mathrm{P}$ and available $\mathrm{P}$ content are commonly found with the use of different biomasses to produce biochars (Novak et al. 2009; Wang et al. 2012). However, comparisons are usually carried out between residues of heterogeneous chemical and structural compositions, such as between peanut hulls and poultry litter (Novak et al. 2009), or between biosolids and cattle manure (Wang et al. 2012), which rendered differences of up to $2,450 \%$.

Our results indicate that the mixture of mineral $P$ sources with enriched biochar (i.e. biochar formed from biomass and soil) can be a viable alternative to carrying P into soil, considering that the biochar did not affect the availability of $\mathrm{P}$ in the triple superphosphate when added after pyrolysis. Biochars composed of organic and mineral fractions have the benefit of being a recalcitrant product with a gradual release of nutrients (Lin et al. 2013; Chia et al. 2014). In addition, the functional acidic surface groups of the biochar can aid in the availability of $\mathrm{P}$ by blocking the phosphate adsorption sites in the soil mineral phases (Lin et al. 2013).

\section{CONCLUSIONS}

The different biomasses used to produce enriched biochars (rice husks and coffee husks), did not affect the content and forms of P in the biochars. Biochars composed with clayey soil had higher $\mathrm{P}$ content associated with Al oxides and hydroxides when compared to sandy-soil biochars, without affecting the available P content. The thermal treatment of the triple superphosphate resulted in a higher degree of crystallinity of the phosphates and a lower content of available $\mathrm{P}$ in the biochars. Thus, in order to use phosphate biochar as a vehicle for phosphorus in tropical soils, our results indicate that it is more appropriate to mix triple superphosphate after the pyrolysis process. More studies will be needed to test this process under different experimental conditions.

\section{ACKNOWLEDGMENTS}

The authors are grateful to Embrapa Rondônia, Universidade Federal Rural de Pernambuco (UFRPE), Universidad de Santiago de Compostela (CRETUS Strategic Partnership - AGRUP2015/02, co-funded by FEDER-UE), and
Coordenação de Aperfeiçoamento de Pessoal de Nível Superior (CAPES, Brazil) for their financial and logistical support. The authors are also grateful to Dr. Vidal Barrón (Universidad de Córdoba, Spain) for his assistance in interpreting XRD patterns, and to Miss Vanessa Young for editing the English language.

\section{REFERENCES}

Abbasi, T.; Abbasi, S.A. 2010. Biomass energy and the environmental impacts associated with its production and utilization. Renewable \& Sustainable Energy Reviews, 14: 919-937.

Addinsoft. 2016. Xlstat-Pro, Core statistical software. (http://www. xlstat.com). Accessed on 25 Aug 2019.

Behera, B.C.; Singdevsachan, S.K.; Mishra, R.R.; Dutta, S.K.; Thatoi, H.N. 2014. Diversity, mechanism and biotechnology of phosphate solubilising microorganism in mangrove: a review. Biocatalysis and Agricultural Biotechnology, 3: 97-110.

Blackwell, P.; Joseph, S.; Munroe, P.; Anawar, H.M.; Storer, P.; Gilkes, R.J.; Solaiman, Z.M. 2015. Influences of biochar and biocharmineral complex on mycorrhizal colonisation and nutrition of wheat and sorghum. Pedosphere, 25: 686-695.

Brewer, C.E.; Chuang, V.J.; Masiello, C.A.; Gonnermann, H.; Gao, X.; Dugan, B.; Driver, L.E.; Panzacchi, P.; Zygourakis, K.; Davies, C.A. 2014. New approaches to measuring biochar density and porosity. Biomass and Bioenergy, 66: 176-185.

Broggi, F.; Oliveira, A.C.; Freire, F.J.; Freire, M.B.G.S.; Nascimento, C.W.A. 2010. Adsorption and chemical extraction of phosphorus as a function of soil incubation time. Revista Brasileira de Engenharia Agrícola e Ambiental, 14: 32-38.

Cao, X.; Harris, W. 2010. Properties of dairy-manure-derived biochar pertinent to its potential use in remediation. Bioresource Technology, 101: 5222-5228.

Chia, C.H.; Gong, B.; Joseph, S.D.; Marjo, M.E.; Munroe, P.; Rich, A.M. 2012. Imaging of mineral-enriched biochar by FTIR, Raman and SEM-EDX. Vibrational Spectroscopy, 62: 248- 257.

Chia, C.H.; Singh, B.P.; Joseph, S.; Graber, E.R.; Munroe, P. 2014. Characterization of an enriched biochar. Journal of Analytical and Applied Pyrolysis, 108: 26-34.

Cornell, R.M.; Schwertmann, U. 2003. The iron oxides: structure, properties, reactions, occurrences, and uses. 2nd ed. Wiley-VCH Verlag GmbH, Weinheim, 664p.

Cui, Y.; Weng, L. 2013. Arsenate and phosphate adsorption in relation to oxides composition in soils: LCD modeling. Environmental Science \& Technology, 47: 7269-7276.

Cunha, T.J.F.; Madari, B.E.; Benites, V.M.; Canellas, L.P.; Ribeiro, L.P.; Benites, V.M.; Santos, G.A. 2009. Soil organic matter and fertility of Anthropogenic Dark Earths (Terra Preta de Índio) in the brazilian Amazon basin. Revista Brasileira de Ciência do Solo, 33: 85-93.

Denry, I.; Holloway, J.A. 2014. Low temperature sintering of fluorapatite glass-ceramics. Dental Materials, 30: 112-121.

Eriksson, A.K.; Gustafsson, J.P.; Hesterberg, D. 2015. Phosphorus speciation of clay fractions from long-term fertility experiments in Sweden. Geoderma, 241-242: 68-74. 
García-Jaramillo, M.; Cox, L.; Knicker, H.E.; Cornejo, J.; Spokas, K.A.; Hermosín, M.C. 2015. Characterization and selection of biochar for an efficient retention of tricyclazole in a flooded alluvial paddy soil. Journal of Hazardous Materials, 286: 581-588.

Gaskin, J.W.; Steiner, C.; Harris, K.; Das, K.C.; Bibens, B. 2008. Effect of low-temperature pyrolysis conditions on biochar for agricultural use. Transactions of the ASABE, 51: 2061-2069.

Graetz, D.A.; Nair, V.D. 2000. Phosphorus sorption isotherm determination. In: Pierzynski, G.M. (Ed.). Methods of phosphorus analysis for soils sediments residuals and waters. USDA, CSREES Regional Committee, Reston, Virginia, USA, p.35-38.

IPNI. 2018. International Plant Nutrition Institute. Evolução do consumo aparente de N, P, Ke Total de NPK no Brasil. (http://brasil. ipni.net/article/BRS-3132\#evolucao). Accessed on 16 Sep 2018.

Jiang, Y-H.; Li, A-Y.; Deng, H.; Ye, C-H.; Wu, Y-Q.; Linmu, Y-D.; Hang, H-L. 2019. Characteristics of nitrogen and phosphorus adsorption by $\mathrm{Mg}$-loaded biochar from different feedstocks. Bioresource Technology, 276: 183-189.

Kim, P.; Hensley, D.; Labbé, N. 2014. Nutrient release from switchgrass-derived biochar pellets embedded with fertilizers. Geoderma, 232-234: 341-351.

Kimbrough, D.E.; Wakakuwa, J.R. 1989. Acid digestion for sediments, sludges, soils, and solid wastes. A proposed alternative to EPA SW 846 Method 3050. Environmental Science \& Technology, 23: 898-900.

Kitamura, M.; Senna, M. 2001. Effects of preheating on mechanochemical amorphization and enhanced reactivity of aluminum hydroxide. Advanced Powder Technology, 12: 215-226.

Knicker, H. 2007. How does fire affect the nature and stability of soil organic nitrogen and carbon? A review. Biogeochemistry, 85: 91-118.

Lima, H.N.; Schaefer, C.E.R.; Mello, J.W.V.; Gilkes, R.J.; Ker, J.C. 2002. Pedogenesis and pre-Colombian land use of "Terra Preta Anthrosols" ("Indian black earth") of

Western Amazonia. Geoderma, 110: 1-17.

Lin, Y.; Munroe, P.; Joseph, S.; Ziolkowski, A.; van Zwieten, L.; Kimber, S.; Rust, J. 2013. Chemical and structural analysis of enhanced biochars: thermally treated mixtures of biochar, chicken litter, clay and minerals. Chemosphere, 91: 35-40.

Löhr, S.C.; Murphy, D.T.; Nothdurft, L.D.; Bolhar, R.; Piazolo, S.; Siegel, C. 2017. Maghemite soil nodules reveal the impact of fire on mineralogical and geochemical differentiation at the Earth's surface. Geochimica et Cosmochimica Acta, 200: 25-41.

Macedo, R.S.; Teixeira, W.G.; Corrêa, M.M.; Martins, G.C.; VidalTorrado, P. 2017. Pedogenetic processes in anthrosols with pretic horizon (Amazonian Dark Earth) in Central Amazon, Brazil. PLoS One, 12: e0178038.

Meszaros, E.; Jakab, E.; Varhegyi, G.; Bourke, J.; Manly-Harris, M.; Nunoura, T.; Antal, M.J. 2007. Do all carbonized charcoals have the same chemical structure? 1. Implications of thermogravimetry: mass spectrometry measurements. Industrial \& Engineering Chemistry Research, 46: 5943-5953.
Mukherjee, A.; Zimmerman, A.R.; Harris, W. 2011. Surface chemistry variations among a series of laboratory-produced biochars. Geoderma, 163: 247-255.

Novak, J.M.; Lima, I.; Xing, B.; Gaskin, J.W.; Steiner, C.; Das, K.C.; Ahmedna, M.; Rehrah, D.; Watts, D.W.; Busscher, W.J.; Schomberg, H. 2009. Characterization of designer biochar produced at different temperatures and their effects on a loamy sand. Annals of Environmental Science, 3: 195-206.

Novotny, E.H.; Maia, C.M.B. de F.; Carvalho, M.T. de M.; Madari, B.E. 2015. Biochar: pyrogenic carbon for agricultural use - a Critical review. Revista Brasileira de Ciência do Solo, 39: 321-344.

Ramirez-Gutierreza, C.F.; Londoño-Restrepoa, S.M.; del Real, A.; Mondragónd, M.A.; Rodriguez-García, M.E. 2017. Effect of the temperature and sintering time on the thermal, structural, morphological, and vibrational properties of hydroxyapatite derived from pig bone. Ceramics International, 43: 7552-7559.

Reetz Jr., H.F. 2016. Fertilizers and their efficient use. International Fertilizer Industry Association, Paris, 110p.

Ruttenberg, K.C. 1992. Development of a sequential extraction method for different forms of phosphorus in marine sediments. Limnology and Oceanography, 37: 1460-1482.

Schaetzl, R.J.; Anderson, S. 2005. Soils genesis and geomorphology. Cambridge University Press, New York, 817p.

Soil Survey Staff. 2014. Keys to Soil Taxonomy, 12th ed. USDA, National Resources

Conservation Service, National Soil Survey Center, Lincoln, 360p.

Sparks, D.L.; Page, A.L.; Helmke, P.A.; Loeppert, R.H.; Soaltanpour, P.N.; Tabatabai, M.A.; Johnston, C.T.; Sumner, M.E. 1996. Methods of Soil Analysis. Part 3. Chemical Methods. Soil Sicence Society of America, Inc., Madison; Amercian Society of Agronomy, Wisconsin, USA, 1264p.

Tan, K. H. 1998. Principles of soil chemistry. 3rd. ed. Marcel Dekker, Inc., New York, 521p.

Tian, S.; Tan, Z.; Kasiulienè, A.; Ai, P. 2017. Transformation mechanism of nutrient elements in the process of biochar preparation for returning biochar to soil. Chinese Journal of Chemical Engineering, 25: 477-486.

Wang, T.; Camps-Arbestain, M.; Hedley, M.; Bishop, P. 2012. Predicting phosphorus bioavailability from high-ash biochars. Plant and Soil, 357: 173-187.

Yao, Y.; Gao, B.; Fang, J.; Zhang, M.; Chen, H.; Zhou, Y.; Creamer, A.E.; Sun, Y.; Yang, L. 2014. Characterization and environmental applications of clay-biochar composites. Chemical Engineering Journal, 242: 136-146.

RECEIVED: $30 / 09 / 2018$

ACCEPTED: 16/08/2019

ASSOCIATE EDITOR: Valdir Veiga Junior 